\title{
CONCEPTUAL UNDERSTANDING OF SOLUBILITY CONCEPTS AMONG FIRST-GRADE HIGH-SCHOOL STUDENTS•
}

\author{
Marina Stojanovska \\ Institute of Chemistry, Faculty of Natural Sciences and Mathematics, Ss. Cyril and Methodius University, \\ Skopje, Republic of Macedonia \\ e-mail: marinam@pmf.ukim.mk, mmonkovic@yahoo.com
}

\begin{abstract}
A study was conducted to inspect conceptual understanding of solubility concepts among first-grade students and to identify the potentially present misconceptions. A total of 122 high-school students (15-16 years old) were involved in the study and a solubility concept test was administered in order to get insight into their conceptual knowledge. Students were divided into two groups: control group and an experimental one. Only the experimental group was subjected to a conceptual change intervention program.

Descriptive statistics and significance testing were used to analyse and summarize data. Independent-samples $t$-test was used to test the differences in the scores between the control group and the experimental one and between male and female students involved in the study. For multiple-choice questions, four areas of conceptual understanding have been set: satisfactory conceptual understanding, roughly adequate performance, inadequate performance and quite inadequate performance. Furthermore, the findings revealed six misconceptions present in students' minds.
\end{abstract}

Key words: solubility; secondary- and high-school chemistry education; misconceptions; intervention program, conceptual understanding.

\section{INTRODUCTION}

Chemistry is a conceptual subject based on a number of abstract concepts. Thus, it is possible that students may not fully understand such concepts. Moreover, the chemical knowledge is acquired at three levels [1]: the macroscopic, the microscopic and the representational (symbolical) level. In many teaching practices, the microscopic level is neglected and students are being lead from macroscopic directly to symbolical level. Thus, it is likely that some misconceptions appear due to the fact that students do not distinguish between macroscopic and microscopic explanations [2-4]. Many misconcepttions concerning various science topics have been documented $[5,6]$ and many other investigations on misconceptions regarding solutions and solubility are known [7-9]. Still, not all erroneous notions are classified as school-made misconceptions [10]. Sirhan [11] claims that the development of misconceptions may originate from previous knowledge of students [12], the usage of everyday or specific scientific terminology etc.

This study was aimed to get insight into students' understanding of some solubility concepts and to check their capability to transfer their knowledge through the three levels of thinking as well as the ability to use graphs to plot the data. Another important segment in the study was to detect any misconceptions students may have regarding solutions and solubility. An integral part of the investigation was an implementation of the instructional program. Namely, this study was conducted to evaluate the effectiveness of intervention program on cognitive achievement towards solubility concepts of highschool students. The intervention program (that included deepened explanations, drawings, experiments and discussions) was implemented during instruction to facilitate understanding of solubility concepts among students. 


\section{METHODOLOGY}

\section{Objectives of the study}

The main objective of this study was to inspect the conceptual understanding of solubility concepts of first-grade students and to determine whether there are some misconceptions present. Also, students' ability to apply the microscopic level in their explanations and the ability to represent data graphically were tested. Furthermore, the study was aimed at evaluating the effectiveness of an intervention programme on students' achievements. tigated:

The following research questions were inves-

1) Are the differences in the mean scores between the control and the experimental group statistically significant?

2) Is there a difference between male and female students in the testing?

3) Are there any misconceptions present in students' thinking (and what are they)?

\section{Design}

The study consisted of three parts: (1) information on the students' previous achievements in chemistry; (2) applying a conceptual change intervention program (CCIP) and (3) administration of the solubility concept test (SCT). CCIP included deepened explanations, discussions and simple experiments. Also, students were actively involved by writing and drawing what they see and what they think happens at microscopic level. The experiments carried out together in the class consisted of dissolving salt and sugar in water at different temperatures.

\section{Research sample}

The research sample comprised 122 firstgrade high-school students from one high-school in Skopje, Macedonia (15-16 years old) in the 2015/16 school year. Students were divided into two groups: control group (CG) and experimental group (EG). Only the EG was subjected to the intervention program. Details concerning participants involved in the study are given in Table 1.

Table 1. Participants involved in the study

\begin{tabular}{cccc}
\hline \multirow{2}{*}{ Group } & \multicolumn{3}{c}{ Number of participants } \\
\cline { 2 - 4 } & Male & Female & Total \\
\hline CG & 22 & 35 & 57 \\
EG & 33 & 32 & 65 \\
\hline Total & 55 & 67 & 122 \\
\hline
\end{tabular}

\section{Research instrument}

The solubility concept test (SCT) was administered to both CG and EG approximately ten days after all class activities were finished in both groups. The test consisted of ten questions, two of which asked for microscopic level of understanding of the dissolution process, five were multiplechoice questions regarding solubility concepts, one involving the usage of graphs and two open-ended conceptual questions.

\section{Data analysis}

Maximum points for questions 1 and 2 was 1.5 each ( 0.5 for each correct drawing), multiple-choice questions (questions 3-7) were scored by 1 point for correct answer and 0 points for wrong one, and for other questions students could receive $1,0.5$ or 0 points for correct, partially correct and wrong answer, respectively. The maximum score for the SCT was 11. The test scores ranged from 0 to 9 points.

Means, standard deviations (SD) and significance testing were used to analyse and summarize data. Independent-samples $t$-test was used to test the differences between CG and EG and between male and female students involved in the study.

According to the literature [13] the percentage of students who correctly answered the question can serve as an indicator of conceptual understanding. Thus, for the multiple-choice questions, four areas of conceptual understanding have been set:

1) satisfactory conceptual understanding (SCU) if the correct answer is given by $75 \%$ of the students or more;

2) roughly adequate performance (RAP) if this percentage is in a range $50-74 \%$;

3 ) inadequate performance (IP) for percentage range $25-49 \%$ and

4) quite inadequate performance (QIP) if obtained frequency is less than $25 \%$. 
Furthermore, a distractor (wrong answer) chosen by more than $20 \%$ of the students has been considered a misconception [14].

\section{RESULTS AND DISCUSSION}

In this section several aspects are considered. Firstly, the analysis of each question will be given having in mind the potential misconceptions (research question 3), and then the research questions 1 and 2 will be investigated in more details.

The questions 1 and 2 test the students' understanding of microscopic level. Students were required to make drawings of particles of particular substances when dissolving table salt (question 1) and sugar (question 2) in water.

Table 2. Information of the percentage of students' answers in questions 1 and 2

\begin{tabular}{ccccc}
\hline & \multicolumn{2}{c}{ Question 1 } & \multicolumn{2}{c}{ Question 2 } \\
\hline Points & EG & CG & EG & CG \\
\hline 1.5 & 18 & 0 & 37 & 0 \\
1 & 31 & 0 & 17 & 2 \\
0.5 & 37 & 0 & 34 & 0 \\
0 & 14 & 100 & 12 & 98 \\
\hline
\end{tabular}

It seems obvious that little attention is paid on microscopic level in the teaching process. This level of teaching in chemistry is crucial in understanding the behavior of substances and many chemical phenomena. Thus, it is important to introduce activities and teaching methods to increase the students' achievements in this area. The results in the EG are not very satisfying, but improvement is unambiguously noticeable.

Questions 3-7 are multiple-choice questions and information on students' answers regarding these questions is given in the next table. The correct answer (or two accepted answers) is given in bold, and options that represent misconceptions are marked with asterisk.

From the table above it can be noticed that there is sound understanding of the tested knowledge in the third question in both groups, which is denoted as SCU (satisfactory conceptual understanding). Furthermore, no misconceptions have been identified in this question. Therefore, it can be concluded that students don't seem to have any problem classifying the solutions according to their saturation.

In the questions 4 and 5 the effect of temperature on solubility of solids (Q4) and gases (Q5) is considered. As a general rule, the increased temperature causes an increase of the solubility of solids in water, but there are some exceptions in which the substance is more soluble in cold than in hot water. Therefore, both options " $a$ " and " $d$ " were taken as correct ones. In both question 4 and 5 the performance of EG-students was higher than the one of CG-students. This is most likely due to the intervention program applied in the EG.

Two misconceptions were located in the question 5. Namely, the idea that solubility of gases increases as the temperature increases (option "a") were common in both CG and EG. Students seem to think that all substances (regardless of the state of matter) are more soluble at higher temperatures. There was another misconception present only in CG. Namely, $30 \%$ of CG-students thought that the solubility of gases is independent of temperature (option "c").

The analysis of the questions 6 and 7 reveals two interesting notions. The first one is that students from EG and CG had diametrically opposite points of view about the effect of pressure on solubility of solids (question 6). CG-students thought that increased pressure leads to increasing solubility, and EG-group students' opinion was that solubility will decrease in this case. Both statements can be considered as misconceptions as more than $20 \%$ of students have chosen the given distractor.

The second notion that should be mentioned is that CG-students were more successful in question 7 than the EG-students. There are also two misconceptions found in this question: 1) increased pressure leads to decreasing solubility of gases $-34 \%$ of EGstudents, and 2) the pressure doesn't affect the solubility of gases $-25 \%$ of EG-students and $23 \%$ of CG-students. Apparently, concepts tested in the last two questions are not well understood by students and more emphasize should be paid in the learning process. 
Table 3. Information of students' answers in questions 3-7

\begin{tabular}{|c|c|c|c|c|c|}
\hline \multirow[b]{2}{*}{ Question } & \multirow[b]{2}{*}{ Option } & \multicolumn{2}{|c|}{ Percentage of students' answers } & \multicolumn{2}{|c|}{ Area of conceptual understanding } \\
\hline & & EG & CG & EG & $\mathrm{CG}$ \\
\hline \multirow{4}{*}{ Q3 } & $\mathbf{a}$ & 98 & 91 & \multirow{4}{*}{$\mathrm{SCU}$} & \multirow{4}{*}{$\mathrm{SCU}$} \\
\hline & $\mathrm{b}$ & 0 & 2 & & \\
\hline & $\mathrm{c}$ & 2 & 7 & & \\
\hline & $\mathrm{d}$ & 0 & 0 & & \\
\hline \multirow{4}{*}{ Q4 } & $\mathbf{a}$ & 82 & 61 & \multirow{4}{*}{$\mathrm{SCU}$} & \multirow{4}{*}{ RAP } \\
\hline & $\mathrm{b}$ & 11 & 7 & & \\
\hline & $\mathrm{c}$ & 5 & 19 & & \\
\hline & d & 3 & 11 & & \\
\hline \multirow{4}{*}{ Q5 } & $\mathrm{a}$ & $29 *$ & $42 *$ & \multirow{4}{*}{ RAP } & \multirow{4}{*}{ IP } \\
\hline & b & 62 & 26 & & \\
\hline & $\mathrm{c}$ & 5 & $30 *$ & & \\
\hline & d & 2 & 0 & & \\
\hline \multirow{4}{*}{ Q6 } & $\mathrm{a}$ & 17 & $35^{*}$ & \multirow{4}{*}{ IP } & \multirow{4}{*}{ IP } \\
\hline & b & $31 *$ & 11 & & \\
\hline & c & 38 & 44 & & \\
\hline & d & 11 & 7 & & \\
\hline \multirow{4}{*}{ Q7 } & $\mathbf{a}$ & 37 & 60 & \multirow{4}{*}{ IP } & \multirow{4}{*}{ RAP } \\
\hline & b & $34 *$ & 11 & & \\
\hline & $\mathrm{c}$ & $25^{*}$ & $23 *$ & & \\
\hline & d & 2 & 3 & & \\
\hline
\end{tabular}

The findings of the last three questions in the test are rather interesting. CG-students were more efficient in giving full answer to the eighth question, which tested students' graphical interpretation of solubility. However, it should be pointed out that $62 \%$ of EG-students have answered the question 8 (although partially) in comparison to total of $35 \%$ of CG-students (giving full or partial answer). It can be concluded that generally EG-students were more successful in drawing a solubility graph to display solubility at different temperatures. Still, more effort is needed to obtain firm knowledge and sound concept understanding.

Questions 9 and 10 were designed as openended conceptual questions. EG-students performed well only in question 10 . The reason for this is double. Namely, this question is somewhat related to the question 4 , which tested the capability of understanding the correlation of solubility of solids and the temperature change. EG-students showed satisfactory conceptual understanding in question 4 , and seem to being able to transfer this knowledge and give correct answer to question 10. Furthermore, this question has some similarities with one of the experiments that were carried out during the lesson, thus students found it more familiar and easier to answer. The percentage of students' answer to these questions is given in Table 4.

The list of misconceptions found as a result of implementing the solubility concept test to students is given in Table 5 .

Next, regarding research question 1 , an independent-samples $t$-test analysis was conducted to determine if there was any significance difference between achievements of CG-students and EGstudents. The analysis revealed significant difference between these two groups of students (Table 6 ), which means that the intervention program had a positive effect on the learning process of this particular topic.

Table 4. Information of the percentage students' answers in questions 8-10

\begin{tabular}{ccccccc}
\hline & \multicolumn{2}{c}{ Question 8 } & \multicolumn{2}{c}{ Question 9 } & \multicolumn{2}{c}{ Question 10 } \\
\hline Points & EG & CG & EG & CG & EG & CG \\
\hline 1 & 0 & 26 & 26 & 24 & 62 & 16 \\
0.5 & 62 & 7 & 12 & 3 & 11 & 5 \\
0 & 38 & 67 & 62 & 30 & 28 & 63 \\
\hline
\end{tabular}


Table 5. The list of misconceptions detected by the solubility concept test

\begin{tabular}{lcc}
\hline Misconception & $\begin{array}{c}\text { Percentage of misconcep- } \\
\text { tion found in EG }\end{array}$ & $\begin{array}{c}\text { Percentage of misconception } \\
\text { found in CG }\end{array}$ \\
\hline $\begin{array}{l}\text { Solubility of gases increases as the tem- } \\
\text { perature increases (option 5a) }\end{array}$ & 29 & 42 \\
\hline $\begin{array}{l}\text { The solubility of gases is independent of } \\
\text { temperature (option 5c) }\end{array}$ & Not found & 30 \\
\hline $\begin{array}{l}\text { Increased pressure leads to increasing } \\
\text { solubility of solids (option 6a) }\end{array}$ & Not found & 35 \\
\hline $\begin{array}{l}\text { Increased pressure leads to decreasing } \\
\text { solubility of solids (option 6b) }\end{array}$ & 31 & Not found \\
\hline $\begin{array}{l}\text { Increased pressure leads to decreasing } \\
\text { solubility of gases (option 7b) }\end{array}$ & 34 & Not found \\
\hline $\begin{array}{l}\text { The pressure doesn't affect the solubility } \\
\text { of gases (option 7c) }\end{array}$ & 25 & 23 \\
\hline
\end{tabular}

Table 6. Independent-sample $t$-test analysis results for intervention program effect on test scores

\begin{tabular}{cccccc}
\hline Group & $N$ & Mean & SD & $t$ & $p$ \\
\hline CG & 57 & 4.07 & 1.47 & \multirow{2}{*}{-8.17} & \multirow{2}{*}{0.00} \\
\hline EG & 65 & 6.46 & 1.72 & & \\
\hline
\end{tabular}

At this point, it is important to mention that the two groups were identical according to their previous achievements in chemistry. Namely, the results from the independent $t$-test analysis on stu- dents' grades given by their teacher indicate that there isn't any significance difference between EG and CG previous achievements, as can be seen from the Table 7.

Table 7. Independent-sample $t$-test analysis results for students' previous achievements

\begin{tabular}{cccccc}
\hline Group & $N$ & Mean & SD & $t$ & $p$ \\
\cline { 1 - 3 } CG & 57 & 3.19 & 1.27 & \multirow{2}{*}{-0.03} & \multirow{2}{*}{0.97} \\
\hline EG & 65 & 3.20 & 1.61 & & \\
\hline
\end{tabular}

An independent-sample $t$-test was also run to investigate the gender effect on test scores (research question 2). The analysis did not yield any significant difference at 0.05 level between the mean scores of the responses by the females and those of the male participants in the study. The results are presented in the Table 8 .

Table 8. Independent-sample $t$-test analysis results for gender effect on test scores

\begin{tabular}{cccccc}
\hline Gender & $N$ & Mean & SD & $t$ & $p$ \\
\cline { 1 - 3 } Male & 55 & 5.33 & 2.06 & \multirow{2}{*}{0.08} & \multirow{2}{*}{0.93} \\
\hline Female & 67 & 5.36 & 1.97 & & \\
\hline
\end{tabular}

Having in mind the test results of the students, several points need to be addressed concerning this study. The higher scores in the EG showed that the intervention program was successful in facilitating understanding of solubility concepts, enabling students to gain more scientific explanations. Still, some misunderstandings and difficulties seem to be present among students that caused several misconceptions to emerge in both $\mathrm{CG}$ and EG.
There are two things that could be considered in teaching chemistry: 1) the "cognitive conflict" strategy [15] and 2) carefully introducing the new material (ideas or concepts) using visualization techniques (models, animations or computer software) $[16,17]$. The latter is valid especially when three level of thinking are discussed. Although, some drawings and models are presented in the 
textbooks, it is the teachers' creativity to enrich the lesson using different teaching techniques.

Acknowledgements. I would like to express my sincere thanks to Prof. V. M. Petruševski for his valuable and constructive suggestions that greatly improved the manuscript. His willingness to give his time so generously has been very much appreciated.

\section{REFERENCES}

[1] H. Johnstone, Teaching of chemistry - logical or psychological?. Chem. Educ. Res. Pract., 1 (2000), pp. 9-15.

[2] B. Bucat, Pedagogical content knowledge as a way forward: Applied research in chemistry education. Chem. Educ. Res. Pract., 5 (2004), pp. 215-228.

[3] A. L. Chandrasegaran, D. F. Treagust, M. Mocerino, The development of a two-tier multiplechoice diagnostic instrument for evaluating secondary school students' ability to describe and explain chemical reactions using multiple levels of representation. Chem. Educ. Res. Pract., 8 (2007), pp. 293-307.

[4] M. R. Meijer, Macro-meso-micro thinking with structure-property relations for chemistry education. An explorative design-based study, Dissertation, Utrecht University (2011).

[5] C. Horton (with other members of the Modeling Instruction in High School Chemistry Action Research Teams at Arizona State University), Student Alternative Conceptions in Chemistry, 2007, retrieved from https://www.google.com /url? sa =t\&rct=j\&q=\&esrc=s\&source=web\&cd=1 $\&$ cad $=$ rja\&uact $=8 \&$ ved $=0$ ahUKEwjTrrKC5vjQAh UByRQKHRBKDxQQFggZMAA\&url=http\%3A $\%$ 2F\%2Fmodeling.asu.edu $\% 2$ Fmodeling $\% 2 \mathrm{FChe}$ m-AltConceptions3-09.doc\&usg=AFQjCNHCL_B Viacs-jmpwmPV49WostSduQ\&sig2 $=1 \mathrm{kwS} 9 \mathrm{~h} 4 \mathrm{Ri}$ 3ORKrF6Rmm8kQ\&bvm=bv.142059868,bs.2,d.b Gg (16 December 2016).

[6] V. Kind, Beyond Appearances: Students, Misconceptions about Basic Chemical Ideas (2 $2^{\text {nd }}$ edition), Durham University, Durham, 2004.
[7] M. Özden, Prospective science teachers' conceptions of the solution chemistry, J. Balt. Sci. Educ., 8 (2009), pp. 69-78.

[8] S. Maass, S. J. Krause, The effect of incorporating youtube videos into an intervention addressing students' misconceptions related to solutions, solubility, and saturation, $121^{\text {st }}$ ASSE Annual Conference \& Exposition, Indianopolis, Indiana, 2014, pp. 1-17.

[9] M. Çalık, A. Ayas, A cross-age study on the understanding of chemical solutions and their components, International Education Journal, 6 (2005), pp. 30-41.

[10] H. D. Barke, A. Hazari, S. Yitbarek, Students' misconceptions and how to overcome them, in: Misconceptions in Chemistry. Addressing Perceptions in Chemical Education, SpringerVerlag, Berlin, 2009.

[11] G. Sirhan, Learning difficulties in chemistry: An overview, J. Turkish. Sci. Educ., 4 (2007), pp. 2-20.

[12] J. Roschelle, Learning in interactive environments: Prior knowledge and new experience, in: J. H. Falk \& L. D. Dierking (Eds.), Public institutions for personal learning: Establishing a research agenda, Washington, DC: American Association of Museums, 1995, pp. 37-51.

[13] J. K. Gilbert, The study of student misunderstandings in the physical sciences. Res Sci Educ, 7 (1977), pp. 165-171.

[14] H. S. Dhindsa, D. S. Treagust, Conceptual understanding of Bruneian tertiary students: Chemical bonding and structure, Brunei Int. J. Sci. Math. Educ., 1 (2009), pp. 33-51.

[15] G. Demircioğlu, Comparison of the effect of conceptual change texts implemented after and before instruction on secondary school students' understanding of acid-base concepts, Asia-Pac. Forum Sci. Learn. Teach., 10 (2009), Article 5.

[16] T. J. José, V. M. Williamson, Molecular visualization in science education: An evaluation of an NSF-sponsored workshop, J. Chem. Educ., 82 (2005), pp. 937-943.

[17] R. W. Milne, Animating reactions. A low-cost activity for particle conceptualization at the secondary level, J. Chem. Educ., 76 (1999), pp. $50-51$. 


\title{
КОНЦЕПТУАЛНО ЗНАЕЊЕ ВО ВРСКА СО РАСТВОРЛИВОСТА КАЈ УЧЕНИЦИ ОД ПРВА ГОДИНА ГИМНАЗИСКО ОБРАЗОВАНИЕ
}

\author{
Марина Стојановска \\ Институт за хемија, Природно-математички факултет, Универзитет „Св. Кирил и Методиј”, \\ Скопје, Република Македонија \\ e-mail: marinam@pmf.ukim.mk, mmonkovic@yahoo.com
}

\begin{abstract}
Целта на ова истражување е испитување на концептуалното разбирање на концептот на растворливост кај ученици од прва година и идентификација на евентуално присутните мисконцепции. Во истражувањето беа вклучени вкупно 122 ученика од гимназиско образование (15-16 години) на кои им беше зададен тест на знаење од областа на раствори и растворливост за да се провери нивното концептуално знаење. Учениците беа поделени во две групи: контролна и експериментална. Само учениците од експерименталната група беа подложени на специјално дизајнирани упатства (инструкции) во текот на поучувањето.

За обработка на добиените резултати беше користена описна статистика и статистички тестови. За испитување на разликата во освоените бодови меѓу учениците од контролната и од експерименталната група, како и меѓу постигнувањата на момчињата и на девојчињата вклучени во истражувањето, беше искористен $t$ тест за парови независни примероци. Кај прашањата со повеќечлен избор беа идентифицирани четири области на концептуално разбирање: задоволително, нецелосно, слабо и недоволно. Понатаму, врз основа на наодите од истражувањето беа откриени шест мисконцепциикај учениците.
\end{abstract}

Клучни зборови: растворливост, средно образование, мисконцепции, специјално дизајнирани упатства, концептуално разбирање. 
Grade

Date

Class

\section{Solubility concept test}

1. Table salt dissolves in water. Imagine you have glasses that can enlarge the particles the substances are composed of (atoms, molecules, ions, ...). Draw your images of the particles into the following laboratory beakers.

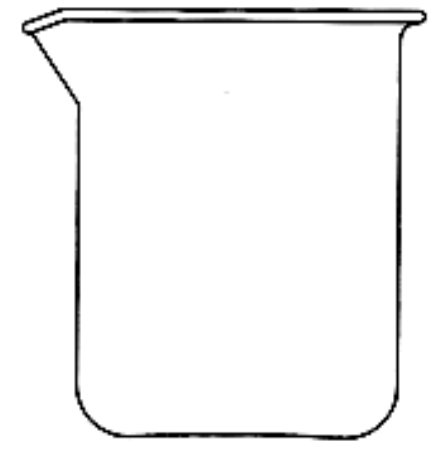

Pure water

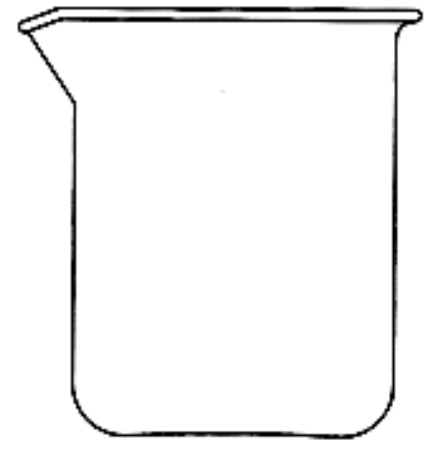

Table salt

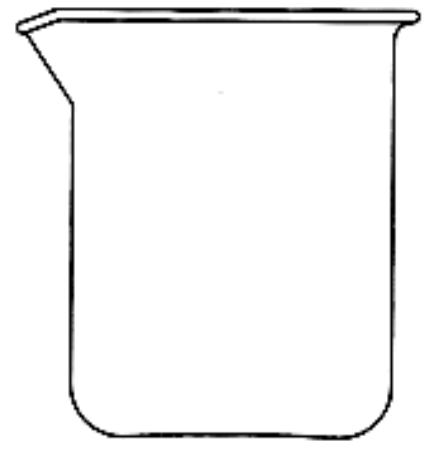

A mixture of water and table salt

2. Sugar dissolves in water. Imagine you have glasses that can enlarge the particles the substances are composed of (atoms, molecules, ions, ...). Draw your images of the particles into the following laboratory beakers.

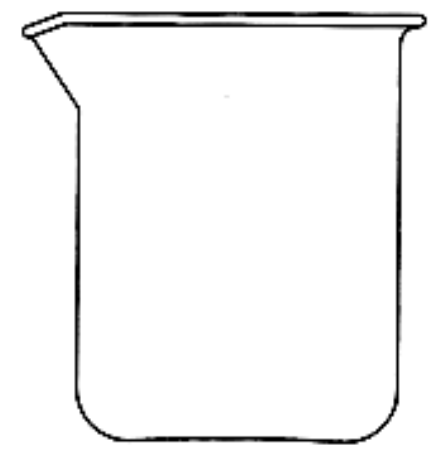

Pure water

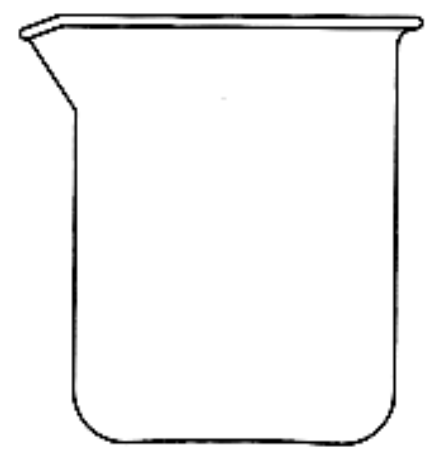

Sugar

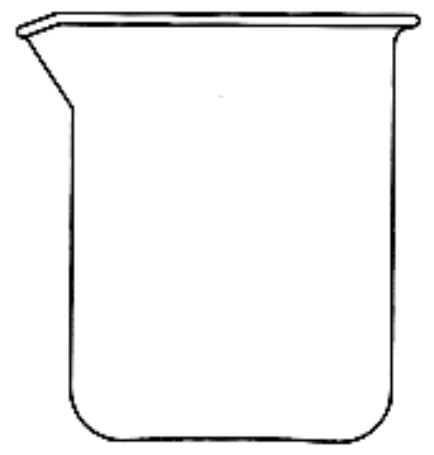

A mixture of water and sugar

3. According to the amount of the dissolved substance, the solutions can be classified as:
a) Unsaturated, saturated and supersaturated
b) Solid, liquid and gaseous
c) Very soluble, soluble, slightly soluble and practically insoluble
d) True solutions and precipitates

4. When the temperature is increased, the solubility of solids in water:
a) Increases
b) Decreases
c) The temperature does not affect
d) There are not enough data to decide

5. When the temperature is increased, the solubility of gasses in water: 

a) Increases
b) Decreases
c) The temperature does not affect
d) There are not enough data to decide

6. When the pressure is increased, the solubility of solids in water:
a) Increases
b) Decreases
c) The pressure does not affect
d) There are not enough data to decide

7. When the pressure is increased, the solubility of gasses in water:
a) Increases
b) Decreases
c) The pressure does not affect
d) There are not enough data to decide

8. Draw a graph to show the dependence of the solubility of potassium nitrate upon the temperature. Label the axes properly. Data are given in the following table.

\begin{tabular}{|c|c|}
\hline $\boldsymbol{s}\left(\boldsymbol{m}\left(\mathrm{KNO}_{\mathbf{3}}\right) / \mathbf{1 0 0} \mathbf{~ g ~ H} \mathbf{H}_{\mathbf{O}} \mathbf{O}\right)$ & $\boldsymbol{T} /{ }^{\circ} \mathbf{C}$ \\
\hline 83.5 & 60.2 \\
\hline 97.5 & 68.9 \\
\hline 125 & 79.8 \\
\hline 167 & 87.2 \\
\hline
\end{tabular}

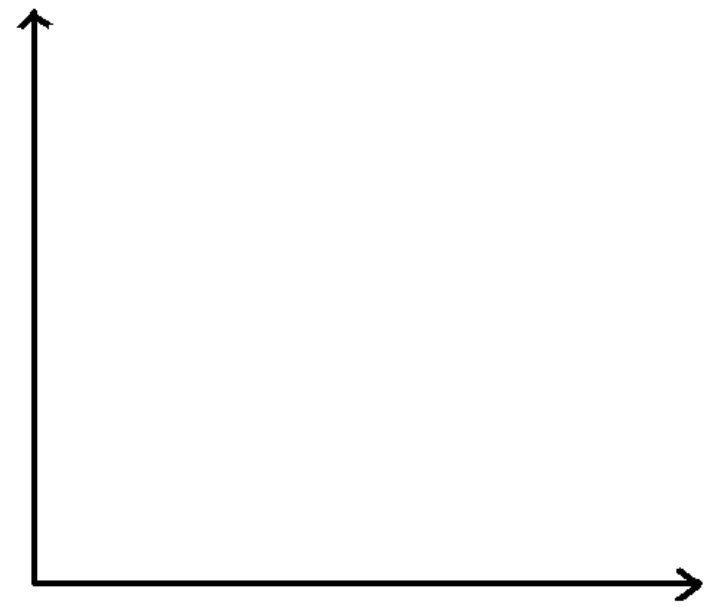

9. Sara bought a fish. When she came home, she put the fish into a bowl with cold boiled water. Few minutes later the fish was dead. Explain what happened.

10. David has two beakers filled with water: cold water in the first and hot water in the second beaker (heated at $100{ }^{\circ} \mathrm{C}$ ). Do you think the same amount of sugar can dissolve in both beakers? Explain you answer. 